\title{
THE CHANGING ROLE OF LOCAL WATER RESOURCES OVER TIME (THE CASE OF SLOVENIAN RURAL REGION - BELA KRAJINA)
}

Tajan Trobec, Barbara Lampič, Dušan Plut ${ }^{1}$

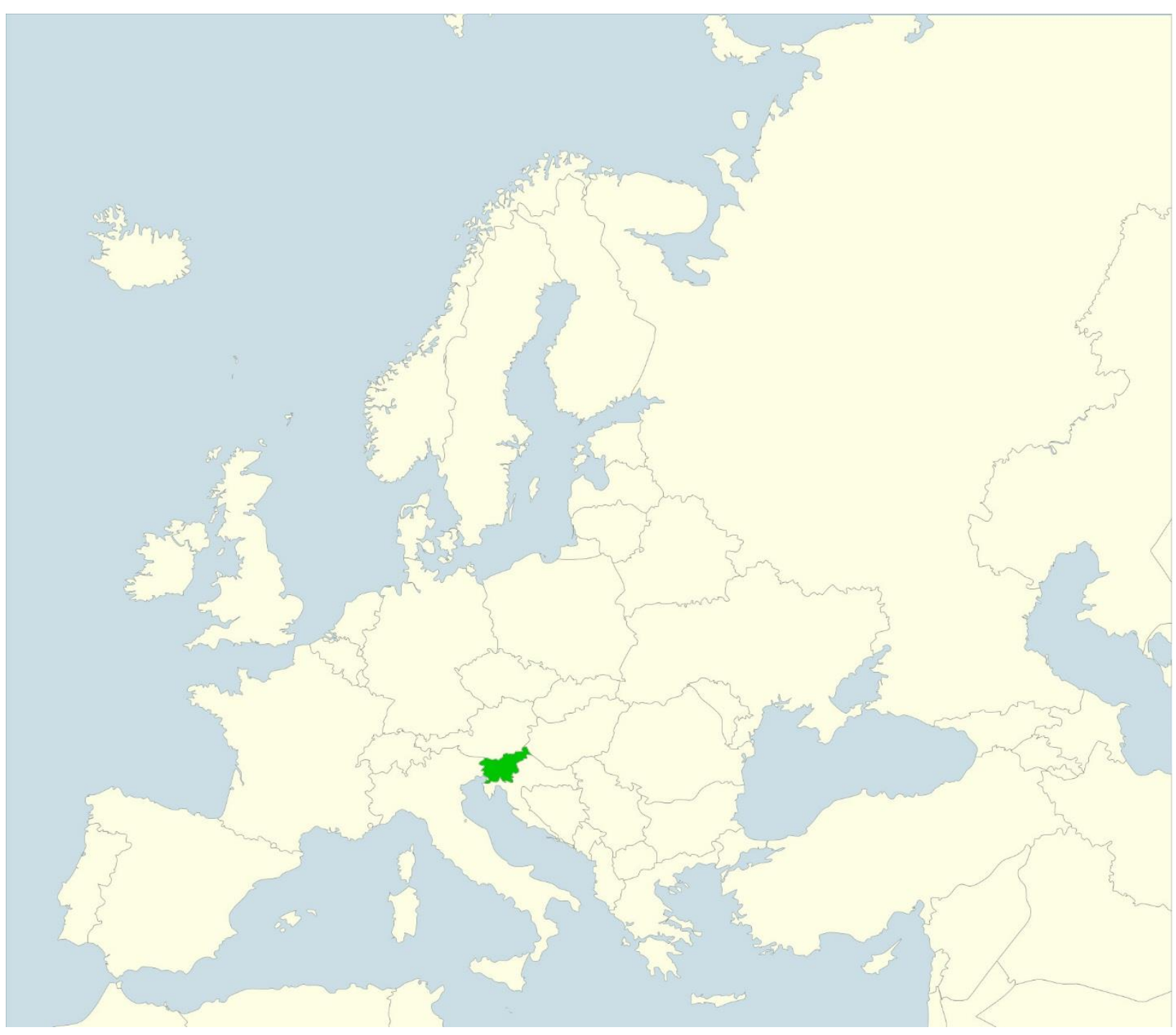

1 Dr. Tajan Trobec, teaching assistant, Ass. Prof. Dr. Barbara Lampič, Prof. Dušan Plut, Department of Geography, Faculty of Arts, University of Ljubljana, Aškerčeva 2, 1000 Ljubljana, tajan.trobec@ff.uni-lj.si; barbara.lampic@ff.unilj.si; dusan_plut@t-2.net 


\begin{abstract}
The article examines issues of local water resources using Bela Krajina as an example - a rural, karst landscape in south-eastern Slovenia. In the field, we made an inventory of 261 different water resources, analysing their past and current use along with their role in the life of the local population and assessing their hydrogeological sensitivity and hydroecological threat they face. With the introduction of distributed water systems, water resources lost their traditional importance in terms of water supply, with local population's reliance on and knowledge about them fading. Nevertheless, certain local communities have recently recognized their natural and cultural value, as well as their importance to ecosystems, which is reflected in initiatives for the preservation, protection and restoration of individual water resources. Most of Bela Krajina's water resources are very sensitive to pollution due to the karst surface, however the actual hydroecological threat they face from human activities in their catchments is relatively low.
\end{abstract}

Key words: water resources, hydrogeological sensitivity, hydroecological threat, vulnerability of water resources, local knowledge, Dinaric karst, Slovenia, Bela Krajina

Abstract: Prispevek obravnava problematiko lokalnih vodnih virov na primeru Bele krajine podeželske, kraške pokrajine $v$ jugovzhodni Sloveniji. Na terenu smo inventarizirali 261 različnih vodnih virov, preučili njihovo nekdanjo in sedanjo rabo ter vlogo $v$ življenju lokalnega prebivalstva in podali oceno njihove hidrogeološke občutljivosti ter hidroekološke ogroženosti. Z izgradnjo vodovoda so belokranjski vodni viri izgubili svoj tradicionalni vodooskrbni pomen, navezanost lokalnega prebivalstva nanje in vedenje o njih pa tone $v$ pozabo. Kljub temu posamezne lokalne skupnosti v zadnjem času prepoznavajo njihovo naravno, kulturno in ekosistemsko vrednost, kar se zrcali $v$ pobudah za ohranjanje, zaščito in obnovo posameznih vodnih virov. Večina belokranjskih vodnih virov je zaradi kraškega površja sicer zelo občutljivih za onesnaževanje, vendar pa je njihova dejanska hidroekološka ogroženost, ki izhaja iz človekovih dejavnosti v zaledju, razmeroma majhna.

Ključne besede: vodni viri, hidrogeološka občutljivost, hidroekološka ogroženost, ranljivost vodnih virov, lokalno znanje, Dinarski kras, Slovenija, Bela krajina

\title{
1. Introduction
}

Water is the source of life and as such is used in almost all human activities from agriculture to transport (Agnew and Woodhouse, 2011). Around the world water demand is continually increasing due to population growth and persistent practices of extensive water use (Aquastat, 2016). Due to limited quantities and its unique role for humanity, water will continue to remain a key natural resource (Donald, 1968; Water in the post-2015 ..., 2014).

In order to provide sufficient quantities of quality water in most parts of the developed world traditional local water resources such as rainwater, springs, wells, karst ponds, etc. have been replaced with water distribution systems. These are often fed from quite distant water resources (Vallentyne, 1972; Ravbar, 2010). Water distribution systems provide water to almost every household, though in this way increase society's dependence on just a few, key water resources. In cases where a water distribution network fails or there is contamination of the water resource entire areas may be completely without water for a long time.

In addition to sufficient quantities of water, its quality is also important for seamless water supply. Various human activities (discharges of waste water, agriculture, industry, etc.) may as a result of thoughtless use lead to permanent contamination of water resources, particularly when they are taking place in areas with poorer self-cleaning capabilities, as is the case in karst areas (Leibundgut 1998; Špes et al., 2002). 
In light of the sustainable development paradigm, recently, the positive impacts of the use of local renewable natural resources (eg. forests, geothermal energy), including water, are increasingly focused on and understood (Blaikie et al., 1997; Vintar Mally, 2011). The role of local water resources is not necessarily limited to the provision of drinking water, thus for certain areas or places it may also represent a significant potential for development (of tourism, energy, etc.).

This paper examines the issues of local water resources using Bela Krajina as an example a rural, karst landscape in the south-eastern part of Slovenia. It focuses primarily on studying the vulnerability of water resources in the area where water is an extremely scarce resource and the changing role of water resources in the lives of the local population over time.

Bela Krajina has very little running surface water, since in the geological past, the majority of the water system shifted to the karst underground (Melik, 1959). Consequently, traditional forms of water supply for the population and domestic animals relied on numerous springs, karst water caves and karst ponds (Plut, 1984), which are also the subject of our research. Additionally, other water resources were also used in Bela Krajina, such as rivers, rainwater, wells, etc., though these are excluded from the survey. Today water supply in Bela Krajina relies on the water distribution network, which is largely fed by a single water source - the high-flow vaucluse karst spring of Dobličica (Brečko Grubar and Plut, 2001). Were it to be contaminated, in spite of some supplementary water resources feeding the water distribution system, the water supply for a large part of Bela Krajina would be threatened. The situation is even more acute, because residents of Bela Krajina have already had a very negative experience of water resource contamination in the past. Namely, due to improper disposal of industrial waste in its delicate water catchment area in the 1980's, the largest karst spring in Bela Krajina - Krupa was permanently contaminated and is still completely useless today in terms of water supply (Polič, 2005).

Although local water resources in Bela Krajina are no longer essential and directly necessary for water supply to the local population (with very few exceptions), the springs and aquatic karst caves, provided there is appropriate protection, represent a potentially important backup source of drinking water, while the village karst ponds and ponds contribute to ensuring ecological balance, landscape and biodiversity, as well as favourable conditions for endangered species and habitat types (Plut, Trobec and Lampič, 2013). Because of their diversity, high-flows and relatively good quality, water resources of Bela Krajina represent one of the development potentials of the entire area. Due to historical, cultural and aesthetic value of certain water resources it might be possible to revive, renew and integrate them into the local tourism offerings. This has already occurred in Bela Krajina in the past (Ivanovič, 2008).

In order to ensure the necessary technical basis for the further management of traditional water resources in Bela Krajina, we took a completely new inventory of the vast majority of Bela Krajina's water resources and thus created an extensive database with multiple attributes. We studied their former use and role in the life of the local population and gave an assessment of their hydrogeological vulnerability and hydroecological threat they face. With the combination of the two indicators, we made an assessment of the regional vulnerability of water resources in Bela Krajina. The methodology used, subject to appropriate adjustments, is transferable to other geographically related areas.

\section{Methodology}

\subsection{Location and description of the study area}

Bela Krajina is a predominantly rural region in the south-eastern part of Slovenia (Figure 1) covering a land area of almost $600 \mathrm{~km}^{2}$. The greater part of Bela Krajina consists of a karst plain which to the north and west extends to the higher karst plateau (Kočevski Rog, Poljanska Gora and Gorjanci). There are very few specimens of non-karst rock. The natural boundaries of the region almost perfectly correspond with administrative borders of three municipalities Črnomelj, Metlika and Semič, as well as with the boundaries of the Lahinja river basin - a central watercourse through Bela Krajina. The Lahinja River flows into the Kolpa River, which marks the southern and eastern part of Bela Krajina, while demarcating the border between Slovenia and Croatia. Most of Bela Krajina's terrain drains into the Kolpa River either through Lahinja and 
its tributaries or via groundwater. The Kolpa River is a tributary of the Sava River, which in turn flows into the Danube River. Hydrogeographically speaking, Bela Krajina therefore forms a part of the Danube River system.

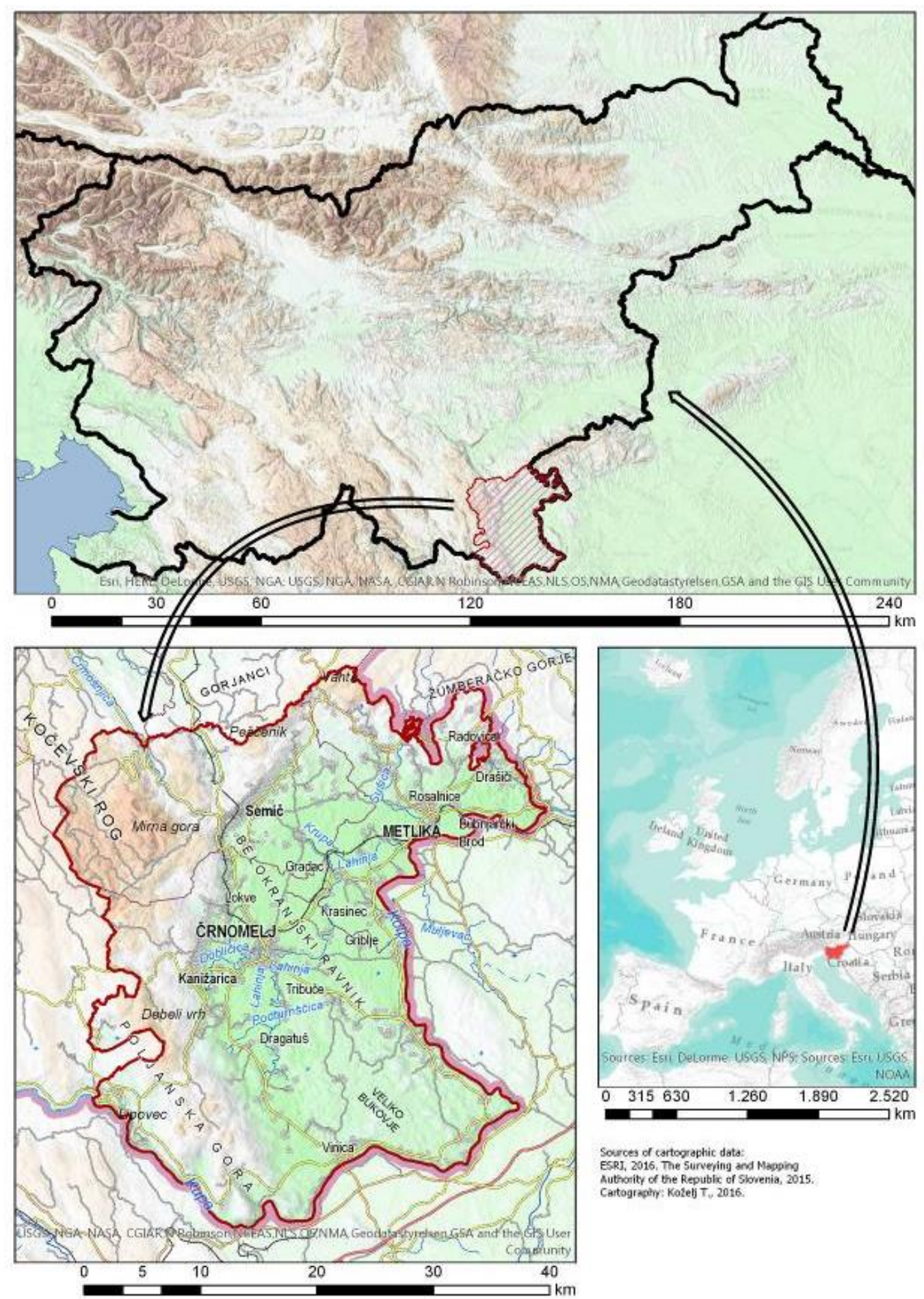

Fig 1. Map of the studied area of Bela Krajina.

Annually, Bela Krajina receives between 1,100 and 1,600 mm of rainfall (Ogrin, 2008). Almost $60 \%$ of rainfall is drained by rivers while the rest evaporates. Specific runoff is measured at $26 \mathrm{l} /\left(\mathrm{s} \times \mathrm{km}^{2}\right)$ (Frantar, 2008) and is about 2.5 times higher than the European average $\left(9.7 \mathrm{l} /\left(\mathrm{s}^{\mathrm{k}} \mathrm{km}^{2}\right)\right)$ (Shiklomanov, 1993). The flow regime of Bela Krajina's waters is conditioned by the rainfall regime which sees moderate prevalence of rainfall in the autumn and pronounced evaporation in summer, with several months of water retention in the form of snow in the higher areas of Gorjanci, Kočevski Rog and Poljanska Gora, as well as the containment of water in 
the karst underground. Judging by the flow regimes of the Lahinja and Kolpa rivers, water resources in Bela Krajina are exceptionally abundant in the colder periods of the year (between October and April), and water levels are lowest during the summer months (July and August), when flow rates fall to approximately $35 \%$ of the average flow rate (Slovenian Environment Agency, 2016).

In 2015 there were 26,707 residents living in a total of 228 settlements (Statistical Office RS, 2016). Settlements are highly dispersed and population numbers are declining due to the region's remoteness from development centres. The region is relatively sparsely populated with less than 45 inhabitants $/ \mathrm{km}^{2}$, however, actual population densities in much of Bela Krajina are even lower - for example, in the municipality of Semič, the figure is only 26 inhabitants $/ \mathrm{km}^{2}$. Scattered settlements and predominantly small settlements with an average of barely 120 inhabitants do not by themselves represent a major threat to the otherwise sensitive karst water resources.

Natural and social conditions also affect land usage, which in Bela Krajina is extremely extensive. The area is dominated by forests (70\%), grassland (14\%) and cultivated fields (7\%) (Ministry of Agriculture, Forestry and Food, 2010). Agricultural activity can be a potential source of water pollution, however this is primarily a risk associated with more intensive forms of production, where greater amounts of mineral and organic fertilizers and plant protection products are used. In Bela Krajina there are relatively low levels of such intensive agriculture.

\subsection{Field work}

In the 1980's there was a detailed study of water resources in Bela Krajina (Plut, 1984), though it did not include systematic spatial analysis nor evaluation of their vulnerability. Since there is no organized database or spatial records for the many small water resources of karstic Bela Krajina, as part of the fieldwork the locations of all three types of studied resources was verified and a variety of descriptive data about them was collected. In terms of the types of water resources, they were categorised as either springs (which were mostly karstic), aquatic karst caves or standing surface water bodies. The bulk of the fieldwork was conducted from mid-May to August 2010. We documented and catalogued 261 water resources.

The fieldwork and registry of water resources, which we set up, were based on a record sheet that we prepared in advance. During fieldwork we sought to obtain as much information as possible for each of the water resources. In addition to precisely locating water resources and determining their basic properties (type of water resource, altitude, present land use, etc.), we also included information about their condition (whether or not they have embankments, are built upon, neglected, accessible, etc.), along with their present use and role as well as the direct and indirect sources of pollution in the immediate and wider areas influencing them. We also measured, or otherwise estimated flows, measured the depth of water in aquatic karst caves and recorded the area and volume of standing surface water bodies. Another important part of the field work was collecting information from the local population. We wanted to collect and preserve as much local knowledge, acquired by locals over the centuries and passed down from generation to generation, which enabled them to survive in the area. We were interested mainly in local nomenclature of water resources, their importance and the forms of past use, as well as information on the permanency of springs, etc.).

A significant number of the studied water resources are today difficult to access and/or heavily overgrown, meaning that it is also difficult to find them. In the field, we were equipped with GPS receivers, digital cameras and devices for performing basic hydrometric measurements.

The established database of Bela Krajina's water resources, managed by the Institute of the Republic of Slovenia for Nature Conservation (Novo Mesto Regional Unit), is designed in such a way that in the future it will be possible to supplement it with newly documented resources or new information on individual resources, though we are confident we included the vast majority of significant water resources. 


\subsection{Methodology for assessing the vulnerability of water resources}

Assessments of the vulnerability of water resources are based on hydrogeological sensitivity and hydroecological threat which are both derived using existing data, as well as using the information we collected in the field. We divided hydrogeological sensitivity and hydroecological threat to water resources into four classes.

In order to determine the hydrogeological sensitivity we analysed hydrogeological conditions and lithologic composition of the catchment areas of springs and aquatic karst caves, while hydrogeological sensitivity of standing water bodies was not determined. The minimum degree of sensitivity was attributed to the springs and aquatic karst caves on impermeable or low permeable alluvial deposits, while greatest sensitivity was attributed to sources on limestone deposits. Springs on carbonate flysch and dolomite were considered to be at an intermediate level of hydrogeological sensitivity.

When determining hydroecological threat we examined a combination of direct and potential pressures on water resources. Direct pressures (such as proximity to houses, septic tanks, stables, manure storage, etc.), which are primarily linked to existing sources of pollution in water resources' immediate area of influence, were measured in the field. Potential pollution, which depends on population density, utilities, transport conditions and use of space in the broader area of influence were determined on the basis of airborne imagery (The Surveying and Mapping Authority of the Republic of Slovenia, 2006) and layered data of land usage (Ministry of Agriculture, Forestry and Food, 2010). A consequence of the karst is that catchments of individual springs can be unknown and groundwater may flow into different river basins. Consequently for small and intermittent springs, assessments of direct hydroecological threat refers to the arbitrarily selected area of influence of $0.1 \mathrm{~km}^{2}$, while for larger and permanent springs this area is up to $0.5 \mathrm{~km}^{2}$. For standing surface water bodies and aquatic karst caves assessments of direct hydroecological threat refer to an area of influence with a radius of about $100 \mathrm{~m}$.

\section{Results and Discussion}

\subsection{Distribution of water resources}

Despite the karst landscape and modest river network the number of water resources in Bela Krajina is relatively large. In the survey we recorded 261, most of which are springs (196 or $75 \%$ ), followed by standing surface water bodies (48 or 18\%) and aquatic karst caves (17 or $7 \%$ ). The density of water resources surveyed was 0.44 resources $/ \mathrm{km}^{2}$. Comparing to previous research in the area (Gams, 1961; Študija vodopreskrbe ... 1967; Plut, 1984; Habič et al., 1990; Janež, 1998; Prelesnik, 2007) we covered most of the area's known water resources (Figure 2). With the help of the local population the survey also captured a number of previously unstudied water resources.

Water resources in Bela Krajina come mainly in the form of springs that are mostly concentrated in the lower sections of the Bela Krajina plain, which runs in an arc from Metlika and Črnomelj through Dragatuš to Vinica. In this area, either because of the shallow karst, where the piezometric level is just below the surface (Natek and Stepišnik, 2008), or else due to the retention of groundwater by less permeable layers (Gams, 1961), the water emerges via a number of high-flow permanent springs. The least number of springs are found in the high altitude areas of Gorjanci, Kočevski Rog and Poljanska Gora. These areas are characterised by karst surface where vertical drainage and underground rainwater flows predominate, which in general come to the surface only in low-lying springs. The area of Veliko Bukovje in the southeast of Bela Krajina, another karstic region that is elevated above the rest of the Bela Krajina plain, has practically no water resources. The groundwater level is deeper below the surface, which explains the absence of springs. In terms of standing surface waters bodies, they are generally village karst ponds and ponds of anthropogenic origin. Karst ponds formed over sinkholes that were closed off by watertight karst loam, subsequently some of them were reinforced with concrete (Plut, 1988). Generally they were set-up in the immediate vicinity of the village. Bela Krajina is also characterised by a number of aquatic karst caves. According to some estimates, the whole region contains over 100 (Gams, 2003). They are small caves or 
cracks in the karst surface, with permanent or intermittent presence of groundwater. They are located in areas where the groundwater is quite close to the surface - this is mostly on the periphery of the Bela Krajina plain.

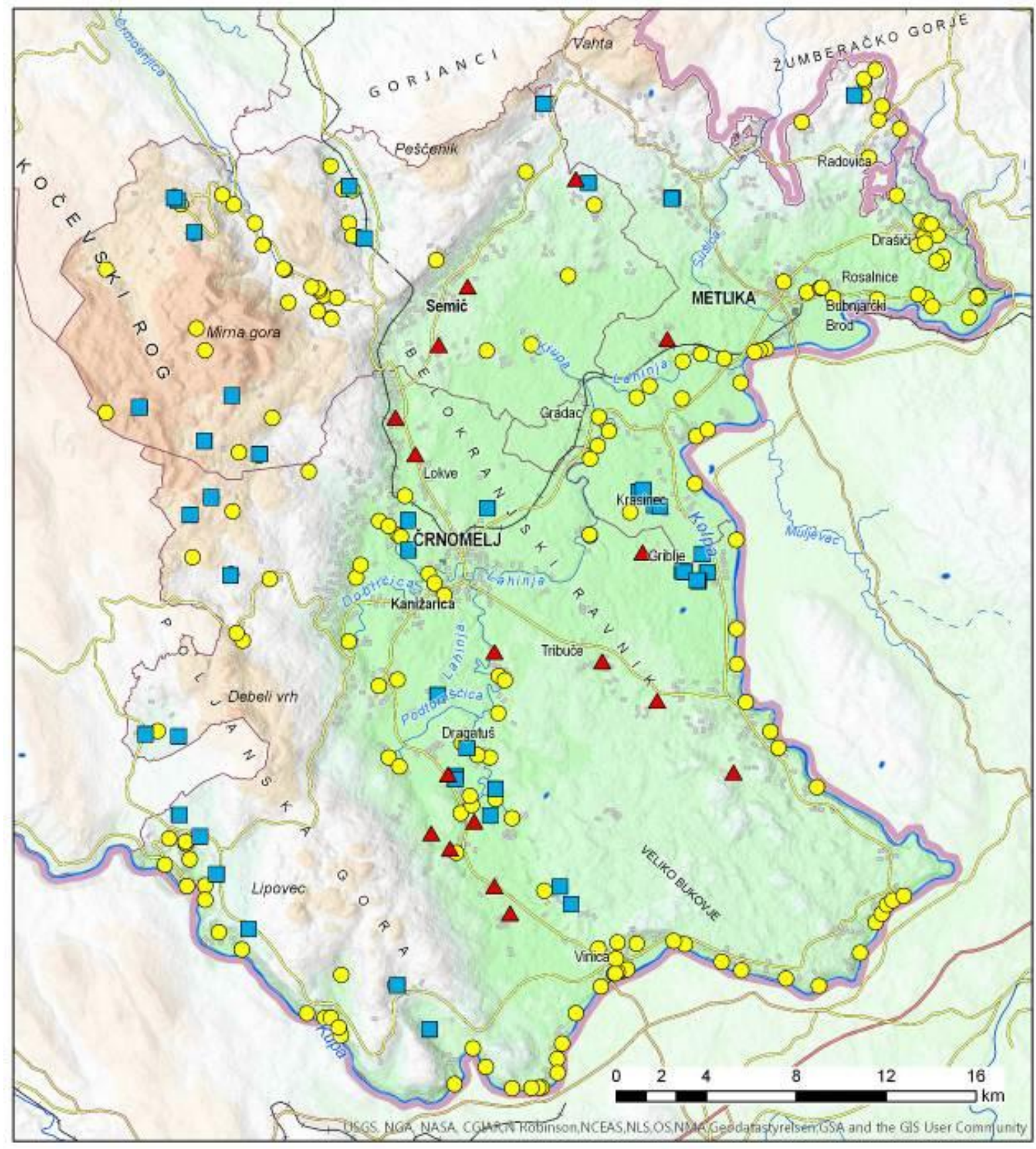

Type of water resource
spring
standing surface water body
A water-containing karst cave

Fig 2. Types of water resources. 


\subsection{Changing uses of water resources over time}

In the past water resources were one of the key factors in the settlement of Bela Krajina. Highflow and permanent water springs and aquatic karst caves were particularly important for the local population's drinking water and general water supply, while karst ponds were intended primarily to provide water for livestock. The use of springs was largely dependent on the magnitude of their flows and permanency. Bela Krajina is dominated by lower-flow springs, with almost threequarters of the spring flows in the dry season of less than $1 \mathrm{l} / \mathrm{s}$. Only 11 springs have a flow rate greater than $10 \mathrm{l} / \mathrm{s}$, with just two springs exceeding $100 \mathrm{l} / \mathrm{s}$ (Krupa and Dobličica). The combined output of Bela Krajina's springs during low water conditions is estimated at $800 \mathrm{l} / \mathrm{s}, 70 \%$ of which is accounted for by Krupa and Dobličica (Plut, 1988) springs. Since 1958 water has been abstracted from the Dobličica spring and today it still represents the main water resource for Bela Krajina's regional water supply (Plut and Brečko Grubar, 2008), while due to improper disposal of industrial waste in its sensitive karst water catchment hinterland, the Krupa spring has been permanently contaminated since the 1980's and thus water was never abstracted for water distribution (Polič, 2005). Almost $60 \%$ of Bela Krajina's springs are permanent, while other springs more or less frequently run dry.

Water resources in karst Bela Krajina have always been of paramount importance for the inhabitants of the area. More than $60 \%$ of resources have been used in the past for various purposes (water supply, drinking water, watering livestock, washing clothes, working in the fields, irrigation...) (Figure 3, Figure 8). Even with the help of the local population, for about a quarter of the resources it was not possible to determine whether they had previously been used and for what purposes. It turns out that the former connectedness of the local population to water resources and the knowledge about them is increasingly diminishing from generation to generation.

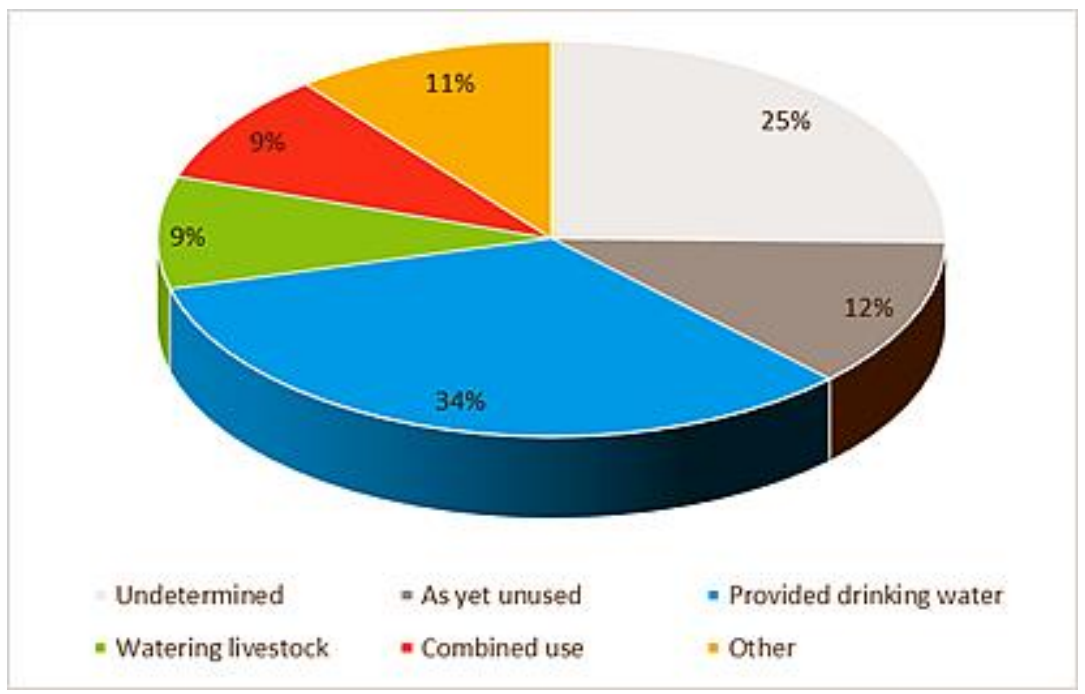

Fig 3. The structure of water resources in Bela Krajina with respect to their former use.

The findings presented in this paragraph refer only to water resources where it was possible to determine their past usage; thus, 144 springs, 36 standing water bodies and 15 aquatic karst caves. In the past just shy of a fifth of resources were not used. They were either too distant or had too little water available or otherwise frequently ran dry. More than half of the resources were used exclusively for drinking water and water supply, while, in combination with other types of use, over $90 \%$ of the springs were used for drinking water and water supply. For watering livestock, in combination with other usages, they once used $15 \%$ of the springs. The springs were also used for watering crops, washing laundry and other combined uses. Similarly important in terms of providing drinking water and water supply were the aquatic karst caves. Nearly threequarters of documented caves were used for such purposes. Plut (1988) arrived at a similar figure, noting that out of about 47 more easily accessible aquatic karst caves about 30 were utilised for accessing water. Standing surface water bodies are mostly of anthropogenic origin. More than 
half of them were previously used for watering livestock, while the rest were used for other reasons (pond, fishpond, wetland, etc.).

In the past, springs had a greater role in water supply and were often developed and made accessible, so that people could more easily extract water. By deepening and reinforcing especially lower-flow and intermittent springs, they were able to take greater advantage of spring water, which was a very valuable asset in those places. The springs were reinforced with natural materials such as wood and stone and later on concrete was also used. In some places they built basins for washing and watering livestock. There are maintained and built-up paths to some of the springs, in a number of cases even stone or masonry stairs. At certain springs they placed statues of Our Lady of Lourdes to watch over the springs so that they would not dry up. In one way or another almost half of the springs are reinforced and developed, which really captures the sense of how important the springs were in the lives of the people of Bela Krajina in the past. In order to provide water a majority of aquatic karst caves were also developed (stone steps made them accessible, paths were developed, caves were walled or their surrounding fenced). These caves were particularly important in areas where there were no other sources of water. In some aquatic caves they also installed hand pumps (Plut, 1988). Some of these developed springs are still very well preserved, while others have fallen into disrepair due to lack of use and maintenance. Examining developed springs compared to springs still in a natural state there are no significant differences between them in terms of their flow rates. This indicates that a spring's rate of flow by itself did not have a decisive influence on whether the resource was developed or not. More important was a spring's consistency, in this regard, more than half of all developed springs are permanent with just a third being intermittent springs.

In the past, houses in Bela Krajina's settlements were situated on average approximately 1,250 m in aerial distance from the nearest water resource (spring or aquatic karst cave) used for drinking water and water supply (it may have been used for a combination of uses). This is not an insignificant distance, which testifies to the fact that the inhabitants of Bela Krajina undoubtedly also utilised other means of water supply (in addition to the springs and aquatic karst caves) before the construction of the water distribution system. In the vicinity of running water they accessed water from waterways, for example, from the Kolpa, Krupa and Lahinja rivers, while in areas where there was groundwater, wells were also utilised to ensure water supply (Plut, 1988; Henigsman, 1998). Water was often carried to one's home using pails and wooden buckets, while in more remote places it was transported on wagons - especially during droughts when close-by water resources dried up. In areas where water resources were more distant or too modest, they relied on rainwater for their water supply. In the past roofs drained into so-called village wells which were equipped with a hand pump and basin. Although the use of rainwater only started at the end of the 19th century, later it became the predominant form of water supply for a large part of Bela Krajina. It was not until the introduction of the water distribution system that it was replaced. By the 1980's practically no household's water supply came exclusively from springs, aquatic karst caves and surface water bodies, though these resources were sometimes still used in times of drought as a supplement to rainwater and/or distributed water (Plut, 1988). With the completion of construction of the water distribution system in Bela Krajina, which included modernisation and expansion of the existing water distribution network (Bela Krajina water distribution network, 2009), the vast majority of the population is now connected to the public water distribution system. The only exceptions are a few small remote villages.

Abandonment of springs and aquatic karst caves was thus associated with the change in water supply means. In addition to springs and aquatic karst caves, village karst ponds also gradually degraded; partly due to lower water demand (declining agriculture and consequent reduction in livestock numbers), and partly the karst ponds were also replaced by rainwater and the water distribution system. Many karst ponds were neglected and became overgrown, some were even filled in. In the past there were many more standing surface water bodies compared to today, as it was previously common for each village to have at least one karst pond. What were once very important water resources for Bela Krajina, today have practically no role in the region's water supply, with the exception of a few springs that feed into the water distribution system. Former ties between people and water resources that used to enable survival have ceased. Thus, when 
the water distribution system brought water from more remote areas to Bela Krajina's households, the knowledge about nearby water sources among residents gradually began to fade.

In recent times, local populations in particular have once again become increasingly aware of the invaluable natural as well as cultural value of nearby water resources (Ivanovič, 1998). It is increasingly understood that they represent an important heritage in certain places, as well as for the entire region. Recognising the value of local water resources is also crucial in terms of their protection from pollution, which is particularly important in the very sensitive karst landscape of Bela Krajina. Furthermore, water resources can also be an integral part of local and regional tourism offerings, which is reflected for instance in the case of the hydrologically very diverse Lahinja Regional Park (Ivanovič, 2008; Plut and Brečko Grubar, 2008; Repe, 2008), although potential benefits are far from being exhausted. Increasingly there is a desire to understand and protect local water resources along with a tendency to manage and restore them, which is also manifested in a number of successfully completed restorations of Bela Krajina water resources (Figures 9-11).

\subsection{Vulnerability of water resources}

Bela Krajina's very high hydrogeological sensitivity is largely due to geological conditions, namely the prevalence of calcareous, karst rocks. Due to their water quality and economically viable volumes, karst aquifers in Slovenia are promising long-term resources that can be considered strategic assets (Ravbar, 2007). At the same time karst aquifers compared to non-karst aquifers are particularly vulnerable to pollution. This is because in karst areas infiltration into the underground occurs extremely quickly due to high permeability and usually absent or else very thin protective covers of soil (Leibundgut, 1998). The more significant karst springs usually have a very large catchment area and possible pollutants anywhere in the catchment area can rapidly enter and jeopardize or otherwise reduce their quality. High flowrate of groundwater in karst (up to several hundred meters per hour) cannot provide sufficient decomposition of pollutants and greater distance from a water resource does not necessarily mean greater security against pollution (Ravbar, 2007).

Due to the complex lithological and tectonic structure of Bela Krajina karst aquifers are arranged differently and in most cases run on several layers. Underground hydrological conditions cannot be explained by knowledge of the geological structure alone, thus it is necessary to utilise a variety of methods, which, in addition to geological interpretations of the area, include speleological characteristics and tracking of underground karst waters using natural or artificial dyes (Natek and Stepišnik, 2008).

Springs as well as aquatic karst caves that were classified as having the highest hydrogeological sensitivity included those water resources whose catchment areas are dominated by limestone. In Bela Krajina limestone is the most widespread rock, thus more than $58 \%$ of documented catchment areas of springs and aquatic karst caves are classed as having very high sensitivity to pollution (Figure 4, Figure 7). This means that even relatively modest pollution in sensitive catchments can cause significant contamination of water resources. The most sensitive water resources are in the low areas of the Bela Krajina plain, where the largest karst springs (Krupa, Dobličica, Lahinja spring, etc.) are located. These springs are partly fed by waters from the lower karst, while water also drains into them from the higher limestone hinterland of Kočevski Rog, Poljanska Gora and Gorjanci. Water resources classed as highly hydroecologically sensitive (accounting for more than a quarter of all water resources) cover those where there is a predominance of dolomite in the catchment areas. These are mainly in the higher north-western area of Bela Krajina. Only a handful of springs are classed as having moderate and low-sensitivity, with catchment areas based on flysch or otherwise impermeable and low permeable alluvial deposits.

Indicative assessments of hydroecological threat are based on actual and potential pollution of all the three types of studied water resources. The vast majority of Bela Krajina's water resources have catchment areas covering smaller areas that are usually sparsely populated and pollution pressures are low. Therefore, almost half of the documented water resources in Bela Krajina are classed as facing low (46\%) or moderate (28\%) hydroecological threats (Figure 5, Figure 7 ). Most 
of them are spatially concentrated in the higher, predominantly forested foothills of Gorjanci and Kočevski Rog and on the outskirts of Veliko Bukovje (a large number of springs near the Kolpa River).

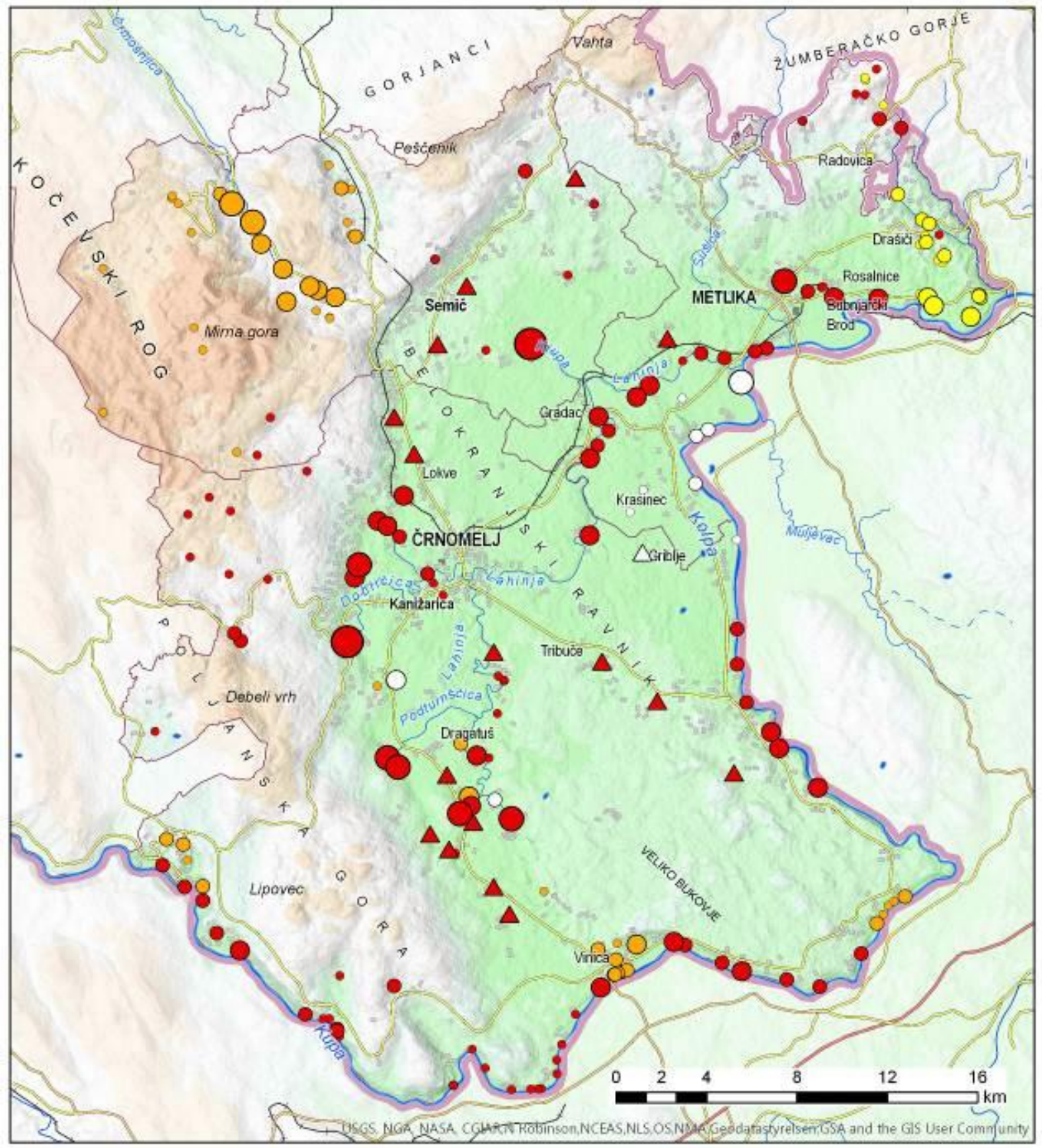

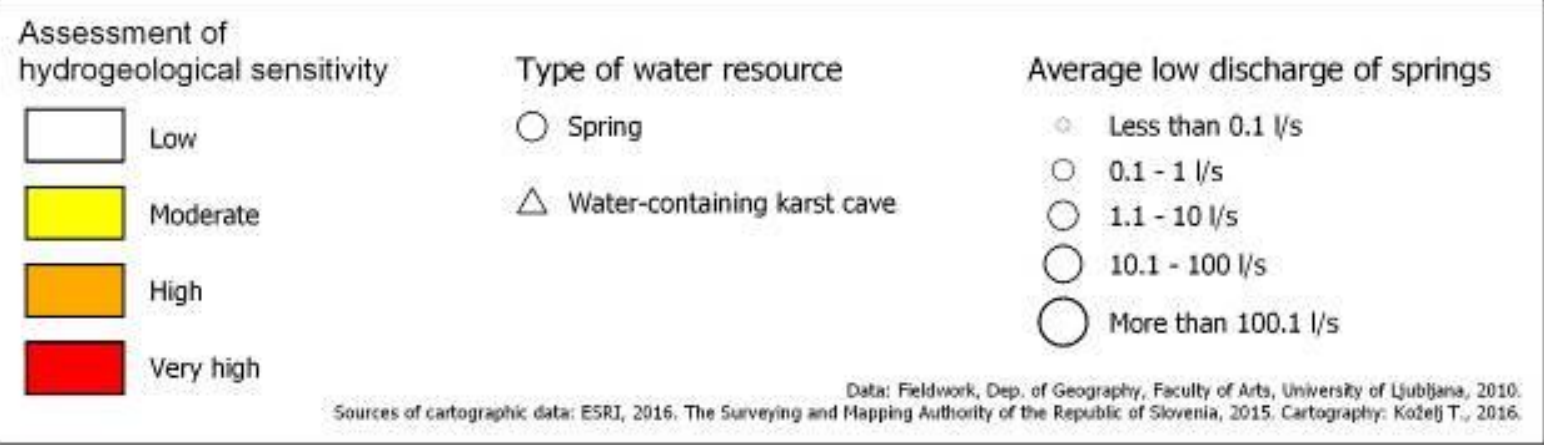

Fig 4. Assessment of hydrogeological sensitivity. 
Although water resources exposed to high (17.6\%) and very high (8.4\%) hydroecological threat are less common, significantly these categories include a number of larger springs with expansive catchment areas. Such resources are also important in terms of water supply (e.g. the Dobličica and Metliški Obrh springs). It is also necessary to acknowledge that assessments of hydroecological threat to water resources did not take into account possible high water levels of Kolpa, Lahinja and Dobličica rivers along with other watercourses, which could lead to rivers flooding and inundating many nearby springs and aquatic caves, consequently degrading their water quality.

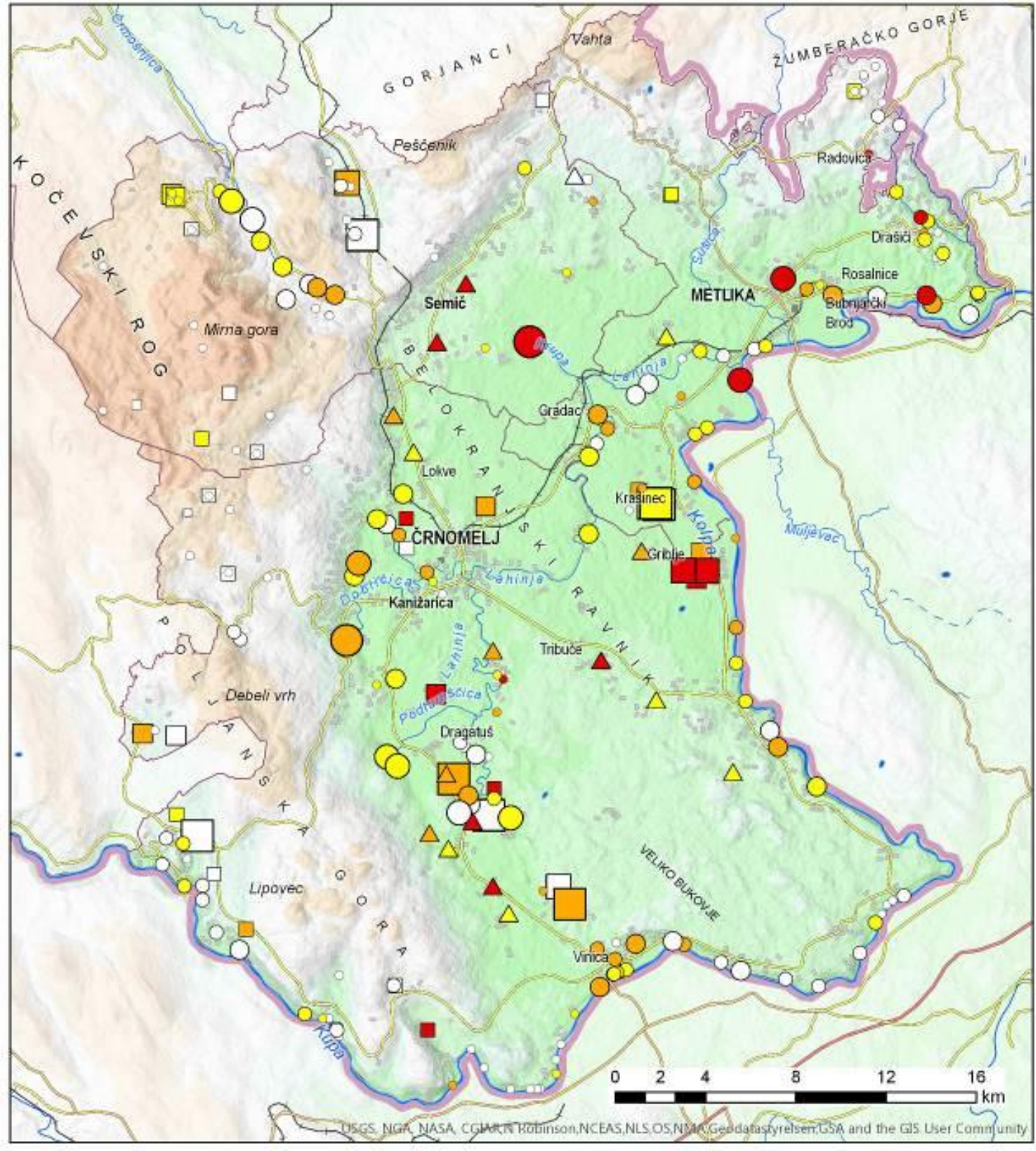

Assessment of hydroecological threat

$\square$ Low

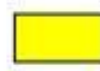

Moderate

High

Very high
Area of standing surface water body

Type of water resource

Spring

$\triangle$ Standing surface water body

Water-containing karst cave

ㅁ $11-100 \mathrm{sq} \mathrm{m}$

$\square \quad 101-500$ sq m

$\square 01-1,000 \mathrm{sq} m$

$1,001-10,000$ sq m
Average low discharge of springs

- Less than $0.1 \mathrm{l} / \mathrm{s}$

$0.1-1 \mathrm{l} / \mathrm{s}$

- $1.1-10 \mathrm{l} / \mathrm{s}$

$10.1-100 \mathrm{~V} / \mathrm{s}$

More than $100.1 \mathrm{l} / \mathrm{s}$

Data: Fieldwork, Dep. of Geographer, Faculty of Ants, University of Isubljana, 2010

Fig 5. Assessment of hydroecological threat. 
Despite the majority of documented water resources having no direct use value or function today, the protection of water as a key natural resource, particularly in the sensitive karst environment, remains of utmost importance. Activities taking place in the immediate vicinity or else catchment areas of resources have the greatest influence on their condition and quality. Through fieldwork (based on site visits) alone it is difficult to develop an expert assessment of the actual impact/pressures caused by a particular activity. Though, it is possible to highlight those activities which, due to the nearby presence of water resources, present actual or potential threats in terms of pollution and reduction of water quality. An initial general assessment of the pressures on a water resource can be made based on the analysis of the dominant land uses in its location or its narrow area of influence.

A more detailed breakdown of land usage by municipality reveals that the most extensive land usage is in the municipality of Semič, where forests cover $79 \%$ of the surface, with fields and vineyards together accounting for barely $2.6 \%$, which is also the percentage for built-up areas. Črnomelj as the largest municipality (and incidentally, where most water resources, 143, are located) has a slightly more intensive use of land; $8 \%$ are fields, vineyards only $0.6 \%$, and orchards (mainly extensive) slightly over one percent. Built-up areas cover $3 \%$ of the municipality. The greatest pressures on water resources are expected in the municipality of Metlika where land use is most intensive. Even by Slovenian standards, in Metlika there is an above-average proportion of fields (14\%), relatively large amount of built-up areas (nearly $5 \%$ ), while the proportion of forest is below average (Ministry of Agriculture, Forestry and Food, 2010).

Field studies reveal that water resources with forested catchment areas dominate. This paints a positive picture in terms of potential pressures. These springs are dominant in the forested areas of Kočevski Rog. Particular attention should be paid to water resources with catchments that include intensive agricultural (5\%), mixed agricultural (23\%) and combined - built-up and agricultural land use (25\%). Thus, almost $55 \%$ of all water resources are located in areas of intensive anthropogenic land usage where there is a constant risk posed by various pollution sources.

Graphical representation of direct and indirect sources of pollution of water resources in Bela Krajina indicates that the direct sources of pollution are relatively few, much more numerous are the so-called potential hazards (Figure 6). More than $50 \%$ of all documented water resources are indirectly threatened by human activities, which necessitates a higher degree of care and attention in future development planning and protection of water resources.

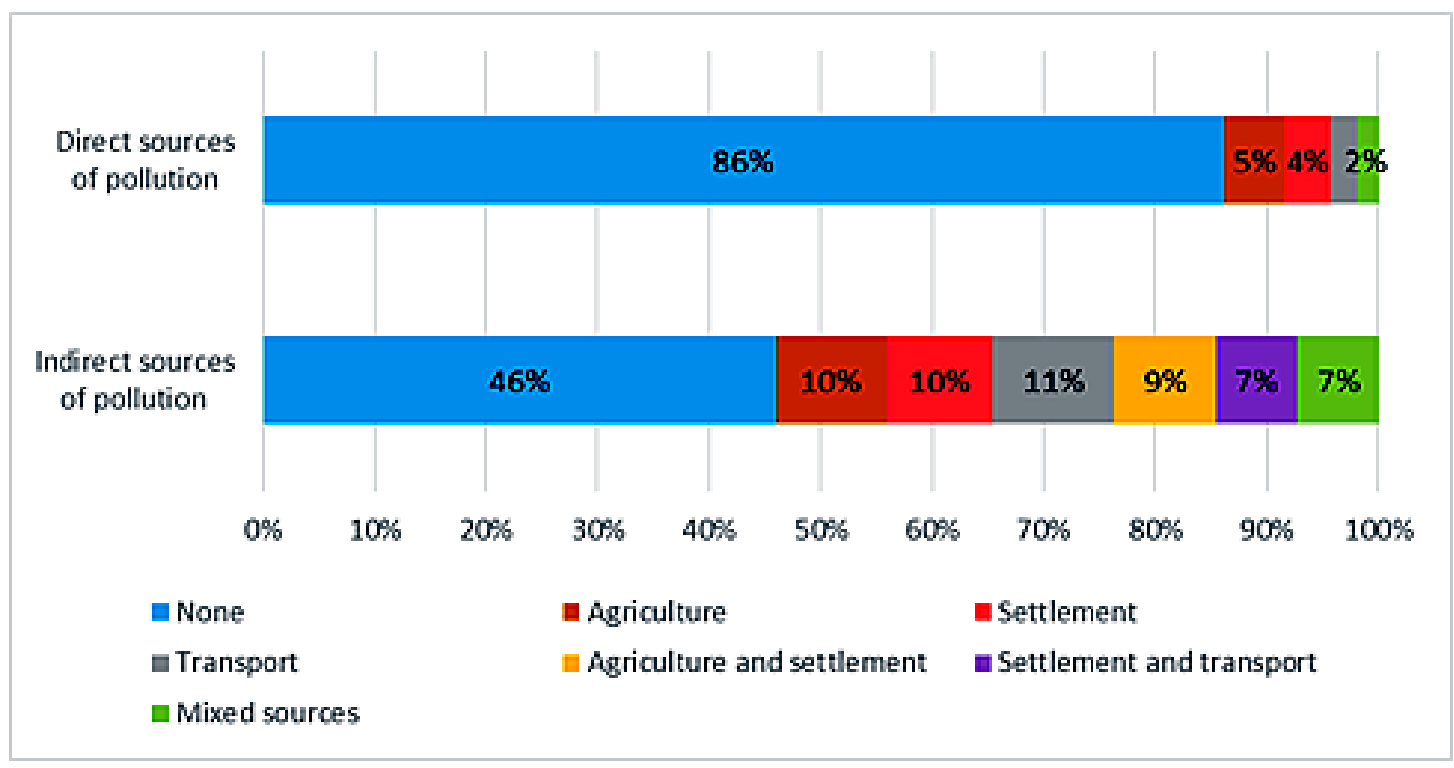

Fig 6. Direct and indirect sources of pollution of Bela Krajina's water resources.

All of Bela Krajina's water resources, not just the springs and aquatic karst caves but also watercourses, are generally considered to be highly or very highly (hydrogeologically) sensitive. 
This is not the case just because of the high hydrogeological sensitivity associated with the karstic hinterlands but also due to the very low average flows of most of the springs in the drier periods (summer), higher summer water temperatures (resulting in lower oxygen content in the water) and a modest gradient of Bela Krajina's watercourses. Comparison of the identified threat and sensitivity assessments of documented springs' and aquatic caves' catchments indicates that their hydrogeological sensitivity is significantly higher than the actual threat they face. Thus, hydrogeological sensitivity of Bela Krajina's water resources is a landscape determinant, to which the scope and degree of pressures should be accordingly adjusted. The latter should be minimal and adjusted to the significantly higher sensitivity during the drier summer conditions.

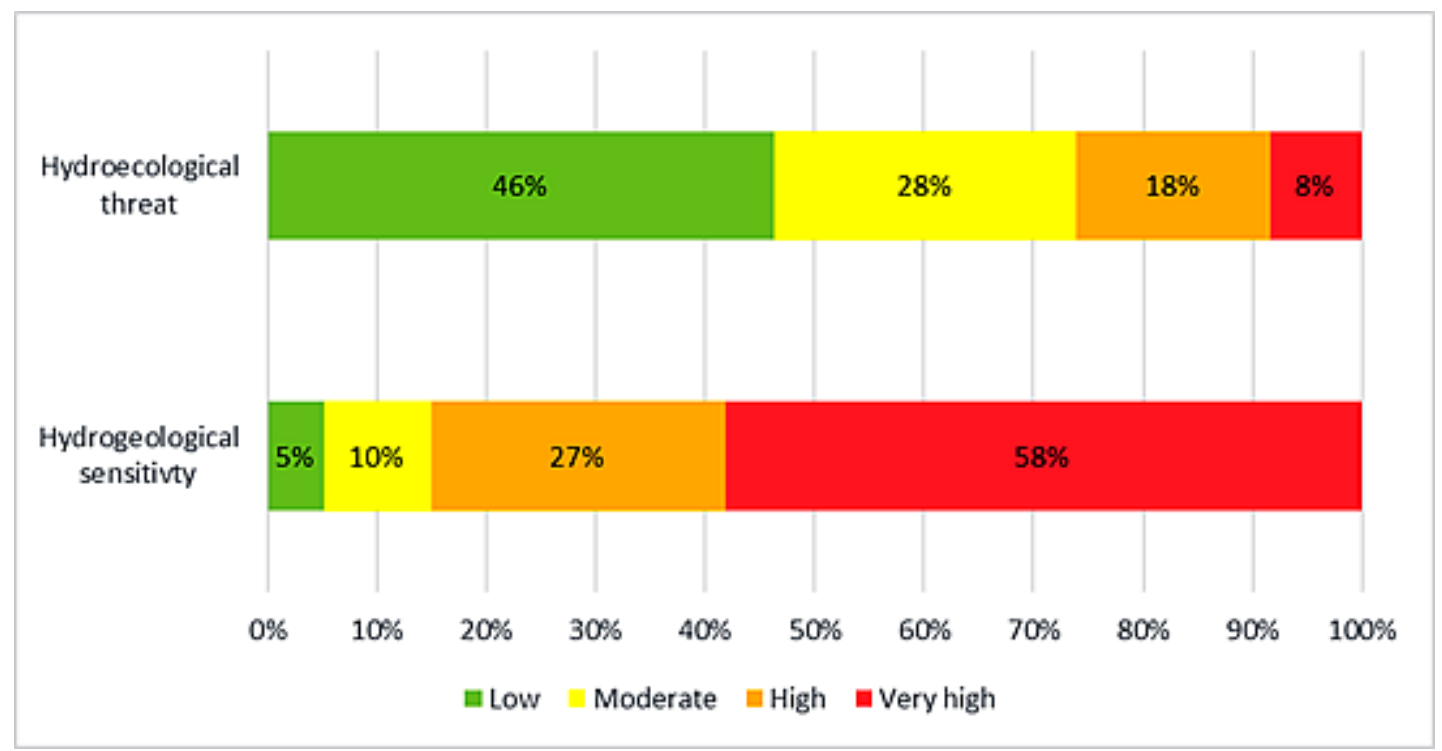

Fig 7. Assessment of hydrogeological sensitivity and hydroecological threat.

The quality of Bela Krajina's predominantly karst water depends entirely on the effective prevention of diffuse and point pollution, since practically all catchment areas of the largest karst springs are almost entirely considered hydrogeologically extremely sensitive. Any additional pressures on sensitive karst springs and aquatic caves in Bela Krajina pose a real and potential threat to the quality of water supply for the population, habitats and sensitive aquatic organisms.

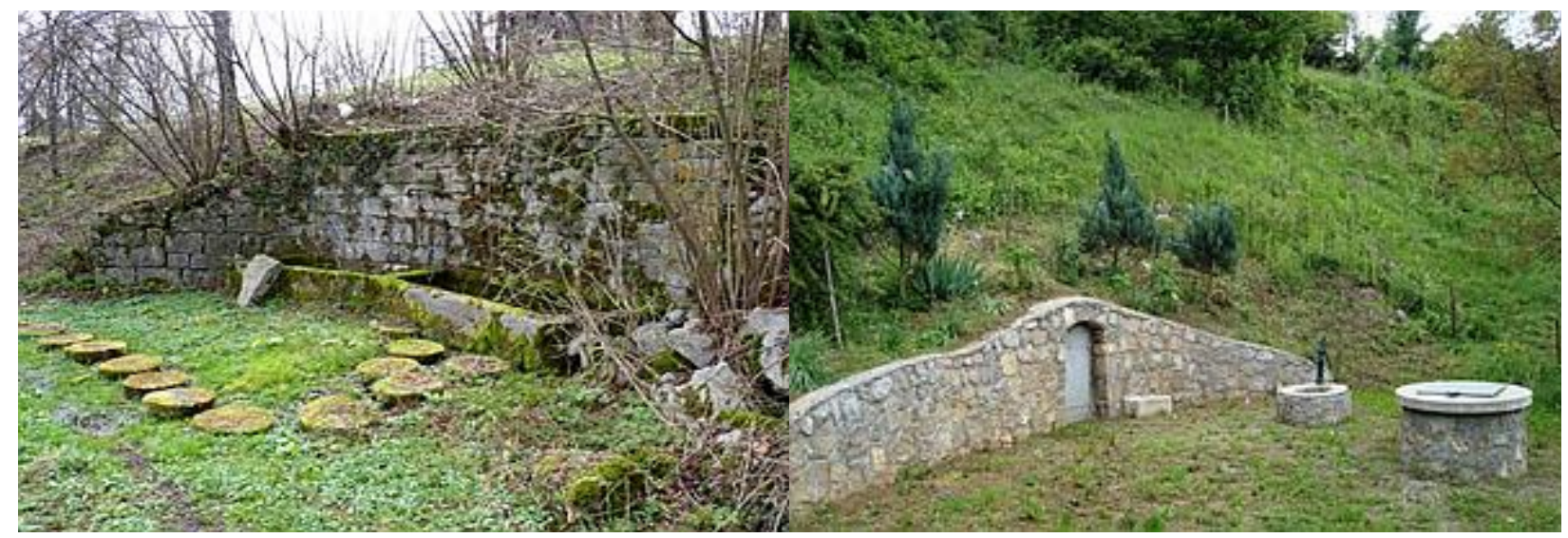

Fig 8. Abandoned spring near Stari Trg ob Kolpi Fig 9. Restored Osojski Zdenec spring. equipped with troughs for watering livestock. 


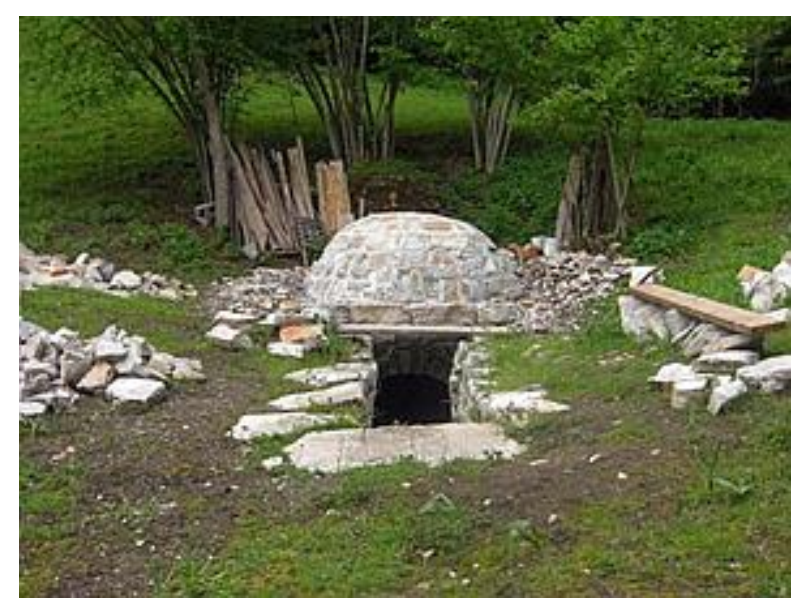

Fig 10. Restored Vodenica aquatic karst cave.

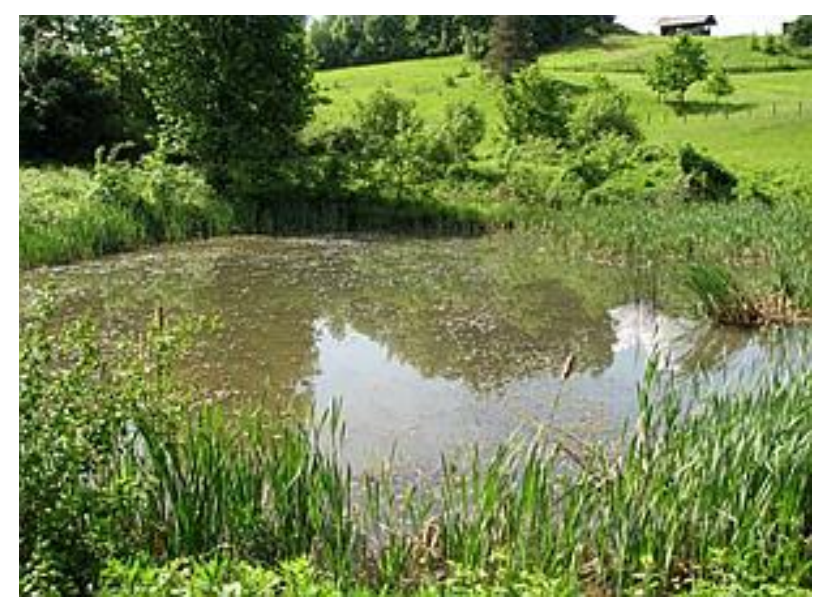

Fig 11. Restored Krivača karst pond.

\section{Conclusion}

Along with suitable arable land, sufficient quantities of quality drinking water were key to life and economic development of the Dinaric karst region in the past (Ravbar, 2010). Sufficient flows and permanency of springs and aquatic karst caves were particularly important in providing drinking water and water supply for local populations, while karst ponds were primarily used for watering livestock. In the past several water resources were developed with access arranged and thus became an important part of the cultural landscape. Since the emergence of modern forms of water supply (rainwater, wells, and water distribution systems) the role of water resources has changed significantly since inhabitants no longer depended on them. This is illustrated in the abandonment and overgrowth of water resources, to the extent that some of them have been completely forgotten. However, recently, people are again recognising the natural and cultural value of water resources and their significance for ecosystems. This is apparent in the growing number of initiatives aimed at their protection, conservation and restoration.

The main findings show that the relatively high vulnerability of examined water resources in Bela Krajina exists more due to the high hydrogeological sensitivity (i.e., the specific natural conditions related to the karstic rocks), and less due to hydroecological threats (direct and indirect effects of human activities). Inventorisation and a broader, multi-faceted evaluation of crucial water resources of Bela Krajina, ongoing and scientifically accurate updating of data, and the maintenance of a permanent register of water resources make up a crucially important basis for strengthening and expanding the role of water resources in the lives of the local inhabitants, livestock, plant and animal life and in this way contributing to the well-being of the population and the conservation of Bela Krajina's ecosystems.

The fieldwork approach along with establishing a formal registry and a system for updating and backing up data is a good model of how to monitor the status of different water resources (including smaller ones with no direct use or identified role), to maintain knowledge about them but also to identify/develop their new functions (for ecosystems, tourism, etc.,.). In this respect, the establishment of a system for monitoring water resources in a Slovenian karst region (of Bela Krajina) is certainly a prime example of science responding to the needs and challenges of regional and local development. 
[1] Agnew, C. \& Woodhouse, P. (2011). Water resources and development, New York: Routledge.

[2] AQUASTAT - FAO's Information System on Water and Agriculture. 2016. AQUASTAT FAO's Information System on Water and Agriculture. Available at:

http://www.fao.org/nr/water/aquastat/water_use/index.stm (Accessed 1 June 2016).

[3] Bela Krajina water distribution network (2009). Available at: http://www.belokranjskivodovod.si (Accessed: 22 April 2016).

[4] Blaikie, P., Brown, K., Stocking, M., Tang, L., Dixon, P. \& Sillitoe, P. (1997). Knowledge in action: Local knowledge as a development resource and barriers to its incorporation in natural resource research and development. Agricultural Systems 55(2), 217-237. Doi: 10.1016/s0308-521x(97)00008-5.

[5] Brečko Grubar, V. \& Plut, D. (2001) Kakovost virov pitne vode v Sloveniji. Ujma, 14/15, 238244.

[6] Donald, B. A. (1968). Water - Our Second Most Important Natural Resource. Boston College Law Review 9(3), 535-552.

[7] Frantar, P., ed. (2008). Vodna bilanca Slovenije 1971-2000. Ljubljana: Ministrstvo za okolje in prostor, Agencija Republike Slovenije za okolje.

[8] Gams, I. (1961). H geomorfologiji Bele krajine. Geografski zbornik 6, 191-240.

[9] Gams, I. (2003). Kras v Sloveniji v prostoru in času. Ljubljana: Založba ZRC.

[10] Habič, P., Kogovšek, J., Bricelj, M. \& Zupan, M. (1990). Dobličica springs and their wider karst background. Acta Carsologica 19, 5-100.

[11] Henigsman, V. (1998). Voda - vir življenja (Povzetek raziskovalne naloge učencev OŠ Belokranjskega odreda Semič). In Ličen Tesari, S., ed., Voda v Beli krajini. Zbornik ob stoletnici napeljave prvega belokranjskega vodovoda 1898-1998 (pp. 6-9). Semič: Občina Semič.

[12] Ivanovič, M. (1998). Vodni viri kot naravna in kulturna dediščina. In Ličen Tesari, S., ed., Voda v Beli Krajini. Zbornik ob stoletnici napeljave prvega belokranjskega vodovoda 18981998 (pp. 10-16). Semič: Občina Semič.

[13] Ivanovič, M. (2008). Krajinski park Lahinja - širše zavarovano območje. In Plut, D., ed., Bela krajina in Krajinski park Lahinja (pp. 25-42). Ljubljana: Znanstvena založba Filozofske fakultete Univerze v Ljubljani.

[14] Janež, F. (1998). Vodni viri na območju Mirne gore. In Ličen Tesari, S., ed., Voda v Beli krajini. Zbornik ob stoletnici napeljave prvega belokranjskega vodovoda 1898-1998 (pp. 2022). Semič: Občina Semič.

[15] Leibundgut, C. (1998). Vulnerability of karst aquifers. In Leibundgut, C., Gunn, J., \& Dassargues, A., eds., Karst hydrology (pp. 45-60). Wallingford: IAHS.

[16] Melik, A. (1959). Posavska Slovenija, Ljubljana: Slovenska matica.

[17] Ministry of Agriculture, Forestry and Food (2010) Available at: rkg.gov.si/GERK/documents/RABA_verzije.rar (Accessed: 12 April 2016).

[18] Natek, K. \& Stepišnik, U. (2008). Geomorfološke značilnosti Bele krajine in Krajinskega parka Lahinja. In Plut, D., ed., Bela krajina in Krajinski park Lahinja (pp. 53-70). Ljubljana: Znanstvena založba Filozofske fakultete Univerze v Ljubljani.

[19] Ogrin, D. (2008). Splošne in lokalne podnebne značilnosti Bele krajine. In Dušan, P., ed., Bela krajina in Krajinski park Lahinja (pp. 71-90). Ljubljana: Znanstvena založba Filozofske fakultete Univerze v Ljubljani. 
[20] Plut, D. (1984). Vode v Beli krajini in njihova uporaba [PhD thesis]. University of Ljubljana.

[21] Plut, D. (1988). Belokranjske vode. Novo mesto: Dolenjski muzej.

[22] Plut, D. \& Brečko Grubar, V. (2008) Hidrogeografske značilnosti Lahinje in Krajinskega parka Lahinja. In Plut, D., ed., Bela krajina in Krajinski park Lahinja (pp. 91-104). Ljubljana: Znanstvena založba Filozofske fakultete Univerze v Ljubljani.

[23] Plut, D., Trobec, T. \& Lampič, B. (2013). Regionalni viri Slovenije. Vodni viri Bele krajine. Ljubljana: Znanstvena založba Filozofske fakultete Univerze v Ljubljani.

[24] Polič, S. (2005). PCB pollution dynamic and environmental impact in the Krupa river karstic region [PhD thesis]. University of Ljubljana.

[25] Prelesnik, A. (2007). Vodni viri na Kočevskem. Ljubljana: Založba ZRC, Društvo Kočevarjev staroselcev.

[26] Ravbar, N. (2007). The protection of karst waters - a comprehensive Slovene approach to vulnerability and contamination risk mapping. Postojna, Ljubljana: Karst Research Institute at ZRC SAZU, Založba ZRC.

[27] Ravbar, N. (2010) Local drinking water supply in karst regions. Dela 34, 223-233. Doi: 10.4312/dela.34.13.223-233.

[28] Repe, B. (2008). Prsti Krajinskega parka Lahinja. In Plut, D., ed., Bela krajina in Krajinski park Lahinja (pp. 121-122). Ljubljana: Znanstvena založba Filozofske fakultete Univerze v Ljubljani.

[29] Shiklomanov, I. A. (1993). World fresh water resources. In Gleich, P. H., ed., Water in crisis. A guide to the world's fresh water resources (pp. 13-24). New York, Oxford: Oxford University Press.

[30] Slovenian Environment Agency (2016) Available at: www.arso.gov.si/vode/podatki/arhiv/Q_obdobne_stat_4000.xls (Accessed: 15 April 2016).

[31] Statistical Office RS (2016) Available at:

http://pxweb.stat.si/pxweb/Dialog/varval.asp?ma=05C4002E\&ti=\&path=../Database/Demog raphics/05_population/10_Number_Population/20_05C40_Population_obcine/\&lang=1 (Accessed: 20 April 2016).

[32] Špes, M., Cigale, D., Lampič, B., Natek, K., Plut, D. \& Smrekar, A. (2002). Študija ranljivosti okolja. Ljubljana: Založba ZRC.

[33] Študija vodopreskrbe za vodovod Bele krajine (1967). Ljubljana: Projekt nizke gradnje.

[34] The Surveying and Mapping Authority of the Republic of Slovenia (2006).

[35] Vallentyne, J. R. (1972). Freswater supply and pollutions. In Polunin, N., ed., The Environmental Future (pp. 181-200). London: The Macmillan Press LTD.

[36] Vintar Mally, K. (2011). Measuring Progress towards Sustainability: the Geographer's view. Hrvatski geografski glasnik 732, 67-80.

[37] Water in the post-2015 development agenda and sustainable development goals (2014) Available at: http://unesdoc.unesco.org/images/0022/002281/228120e.pdf (Accessed: 21 April 2016). 